\title{
Healthy Dwelling: Design of Biophilic Interior Environments Fostering Self-Care Practices for People Living with Migraines, Chronic Pain, and Depression
}

\author{
Dorothy Day Huntsman ${ }^{1}$ (D) and Grzegorz Bulaj ${ }^{2,3, *}$ \\ 1 Dayhouse Studio, Salt Lake City, UT 84106, USA; dorothy@dayhousestudio.com \\ 2 OMNI Self-Care, LLC, Salt Lake City, UT 84111, USA \\ 3 College of Pharmacy, Department of Medicinal Chemistry, University of Utah, 30 South 2000 East, \\ Salt Lake City, UT 84112, USA \\ * Correspondence: bulaj@pharm.utah.edu
}

check for updates

Citation: Huntsman, D.D.; Bulaj, G. Healthy Dwelling: Design of Biophilic Interior Environments Fostering Self-Care Practices for People Living with Migraines, Chronic Pain, and Depression. Int. J. Environ. Res. Public Health 2022, 19, 2248. https://doi.org/10.3390/ ijerph19042248

Academic Editors: Kirsten Kaya Roessler, Brady Wagoner, Sofie Pedersen, Mads Bank and Paul B. Tchounwou

Received: 31 December 2021 Accepted: 13 February 2022 Published: 16 February 2022

Publisher's Note: MDPI stays neutral with regard to jurisdictional claims in published maps and institutional affiliations.

Copyright: (c) 2022 by the authors. Licensee MDPI, Basel, Switzerland. This article is an open access article distributed under the terms and conditions of the Creative Commons Attribution (CC BY) license (https:// creativecommons.org/licenses/by/ $4.0 /)$.

\begin{abstract}
The benefits of biophilic interior design have been recognized by healthcare facilities, but residential environments receive relatively less attention with respect to improving the health of people living with chronic diseases. Recent "stay-at-home" restrictions due to the COVID-19 pandemic further emphasized the importance of creating interior spaces that directly and indirectly support physical and mental health. In this viewpoint article, we discuss opportunities for combining biophilic interventions with interior design, fostering disease-specific self-care. We provide examples of designing residential spaces integrating biophilic interventions, light therapy, relaxation opportunities, mindfulness meditation, listening to music, physical activities, aromatherapy, and quality sleep. These modalities can provide the clinical benefits of reducing migraine headaches and chronic pain, as well as improving depressive symptoms. The disease-specific interior environment can be incorporated into residential homes, workplaces, assisted-living residences, hospitals and hospital at home programs. This work aims to promote a cross-disciplinary dialogue towards combining biophilic design and advances in lifestyle medicine to create therapeutic interior environments and to improve healthcare outcomes.
\end{abstract}

Keywords: built environment; restorative; biophilia; salutogenesis; home care; non-pharmacological interventions; self-management; mental health; neurological disorders

\section{Introduction}

People living with chronic diseases experience both debilitating disease symptoms and diminished health-related quality of life. Chronic pain, migraines and depression are some of the leading causes of disability worldwide [1]. Currently available therapies for chronic diseases include pharmaceutical drugs and non-pharmacological interventions such as behavioral therapies, physical therapies and digital therapeutics. However, despite progress in developing new medical treatments, the global burden of neurological diseases has increased [2].

A sedentary lifestyle significantly contributes to the causes and symptoms of chronic disease [3]. On average, people in the US, Canada and Germany spend 15-17 h per day indoors [4]. "Stay-at-home" restrictions, due to the COVID-19 pandemic, further decreased physical activity, having an adverse impact on mental health [5]. Lifestyle modifications and self-care practices can help patients to improve their health [6-8]. For the purpose of this work, self-care is defined as "the ability of individuals, families and communities to promote health, prevent disease, maintain health and to cope with illness with or without the support of a healthcare provider" (definition by the World Health Organization). Selfcare practices include quality sleep, relaxation, mindfulness practices, listening to music, 
physical activity, healthy nutrition, aromatherapy, stress management and connecting with nature.

Residential environments are often overlooked as a complementary means to improve therapeutic outcomes [9]. The emerging field of biophilic design has been focusing on therapeutic indoor environments for decades [10-17]. The biophilic design philosophy is derived from an inherent need for humans to connect with nature in order to stay in physical and mental balance $[12,18]$. The concept of biophilia suggests that the tendency of humans to affiliate with nature has, in part, a genetic basis, hence the inherent need for connection $[10,18]$. The benefits of nature connectedness include relaxation, stress relief, lower blood pressure and heart rate, decrease in chronic pain, improvement in cognitive functioning, increased positive emotions, and reduced fatigue, aggression and sadness [19-21].

Biophilic design principles are generally organized into three categories: nature in the space, nature of the space and natural analogues $[12,22]$. Nature in the space is creating a visual connection with nature; for instance, using vegetation (plants, flowers and trees) both outside and inside a residential space. Nature of the space is the imitation of natural processes, such as the circadian rhythms through lighting patterns, and spatial compositions found in nature, such as creating a reading nook to give a sense of refuge and safety. Natural analogues are representations of the textures, geometries, materials, colors, shapes and patterns found in the natural world that provide an indirect sense of the great outdoors. The 2015 report by Kellert and Calabrese describes biophilic design principles as providing "repeated and sustained engagement with nature" and focus " on human adaptations to the natural world that over evolutionary time have advanced people's health, fitness and well-being" [11].

In addition to residential spaces, biophilic design is applicable to healthcare facilities [22] and workplaces [23,24]. For example, biophilic design was recently utilized in long-term residential care for people with dementia [25]. Other studies suggest that it can be optimized for people with post-traumatic stress disorder [26], autism spectrum disorders $[27,28]$ and to improve mental health outcomes [29]. The interior design opportunities are further illustrated by reports of biophilic design to mitigate physical and cognitive decline in aging adults [30], and for those living with disabilities [31]. In this viewpoint article, we describe opportunities to expand biophilic design by integrating indoor spaces fostering diverse self-care practices. We provide a rationale for this cross-disciplinary approach to creating therapeutic interior environments for people living with specific chronic diseases.

\section{Integrating Biophilic Design and Self-Care to Create Therapeutic Interior Environments}

Housing is recognized as an important determinant of human health [32], providing multiple opportunities to transform residential indoor spaces into therapeutic environments. Figure 1A illustrates possible relationships between specific residential spaces and healthrelated domains (e.g., affective states, cardiovascular, metabolic, and immune functions). For example, a living room that promotes relaxation (e.g., through biophilic features, soundscapes to deliver music, furniture to foster relaxation and meditation) and physical activities (exercise or yoga practice) can support mental and cardiovascular health. Since quality sleep impacts mental, cardiovascular, neurological and immune functions [33-36], the design of a bedroom that supports sleep hygiene, resting and relaxation (e.g., through biophilic elements, using clean lines, calming colors, cultivating a feeling of intimacy, providing dimmable lighting using "zero-blue" bulbs) can further support people living with chronic diseases. 
A
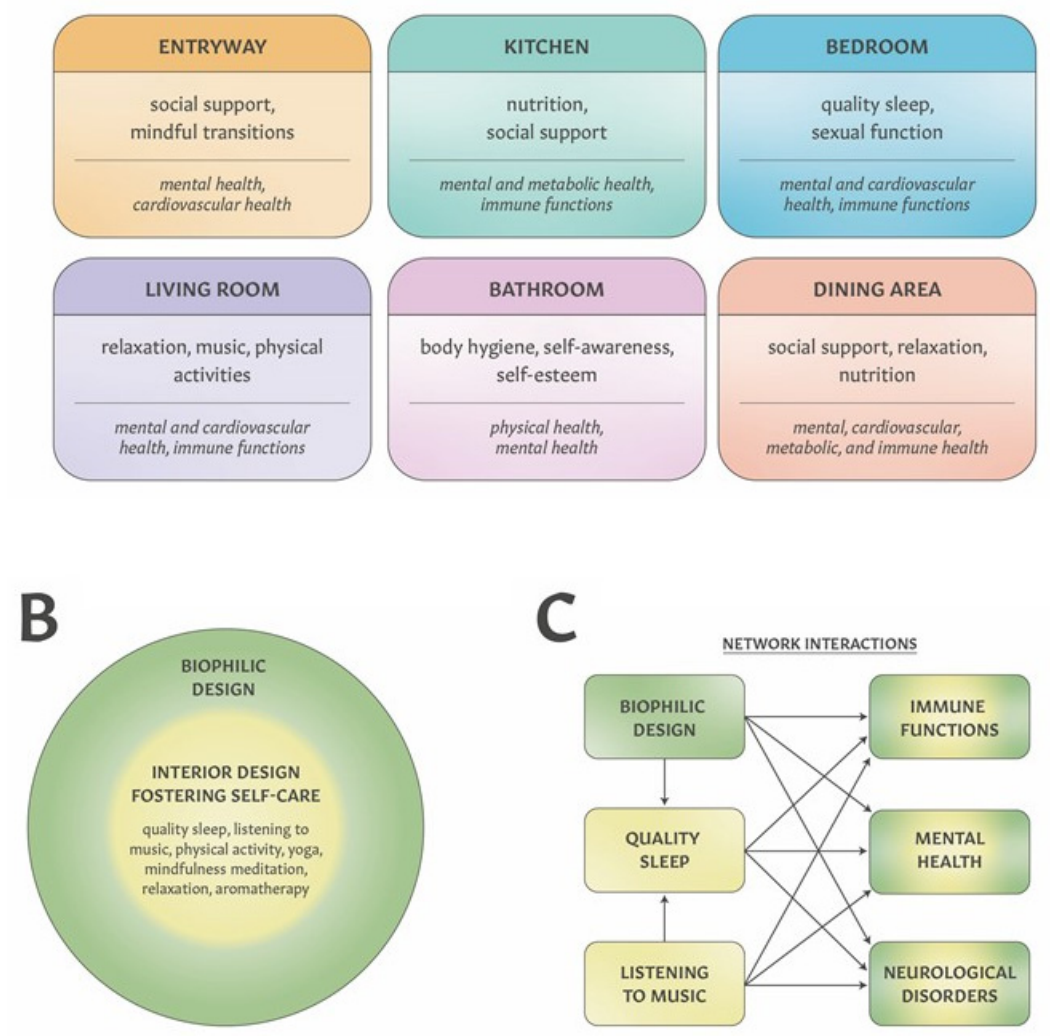

Figure 1. Graphical representation of transforming residential indoor spaces into therapeutic interior environment opportunities by integrating biophilic design and disease-specific self-care. (A) Examples of the relationship between residential indoor spaces, daily functions and health. (B) The concept of therapeutic interior environments created by integrating biophilic design with spaces fostering self-care practices. (C) Potential benefits of integrating biophilic design and selfcare are presented as a network of mutually beneficial interconnections improving health-related outcomes. As an example, both biophilic design and listening to music can improve quality sleep, while all three (biophilic elements, quality sleep and music) have positive effects on mental health, neurological functions and the immune system.

Transforming residential spaces into therapeutic interior environments can be accomplished through combining biophilic design with design features fostering self-care, as shown in Figure 1B. Biophilic design is applicable to any of the residential indoor spaces, including the living room, bedroom, kitchen, dining room, etc. Judicious design of biophilic features throughout the residence can provide a continuum of exposure to indoor nature. Figure $1 \mathrm{C}$ illustrates the prospects of creating mutually beneficial interactions when integrating biophilic design and indoor environments supporting disease-specific self-care. The network of diverse physiological responses to such therapeutic interior environments is supported by accumulating studies showing that nature-based interventions and listening to music can improve depressive symptoms and pain (e.g., [19,37-44] while also improving sleep [45-48]. It is noteworthy that all three-nature-based interventions, listening to music and quality sleep - can also positively impact immune functions $[33,49,50]$. In subsequent sections, we discuss how a combination of interior features (including biophilic design, furniture, lighting, aromatherapy and soundscapes) and self-care practices can be combined to create a therapeutic environment for people living with migraines, chronic pain and depression. 


\section{Therapeutic Interior Design for People with Chronic Diseases}

As described in the Introduction, research shows that biophilic design can yield positive effects on health and well-being $[12,13,17]$. Biophilic interventions have been shown to improve relaxation, reduce stress and depressive symptoms, and provide pain relief $[43,44,51-61]$. Herein, we show examples of residential spaces combining biophilic design principles with beneficial self-care components individualized for persons living with migraines, chronic pain and depression (Figure 2). To provide a rationale for incorporating specific self-care practices into residential indoor spaces, we summarize the clinical benefits of relaxation, mindfulness meditation, listening to music, physical activities, aromatherapy and quality sleep (Tables 1-3). In addition, we describe how advances in light therapy can inspire the design of lighting systems to reduce migraine headaches, chronic pain and depressive symptoms. These descriptions are intended to promote cross-disciplinary discussion on innovative interior design for people living with chronic diseases.

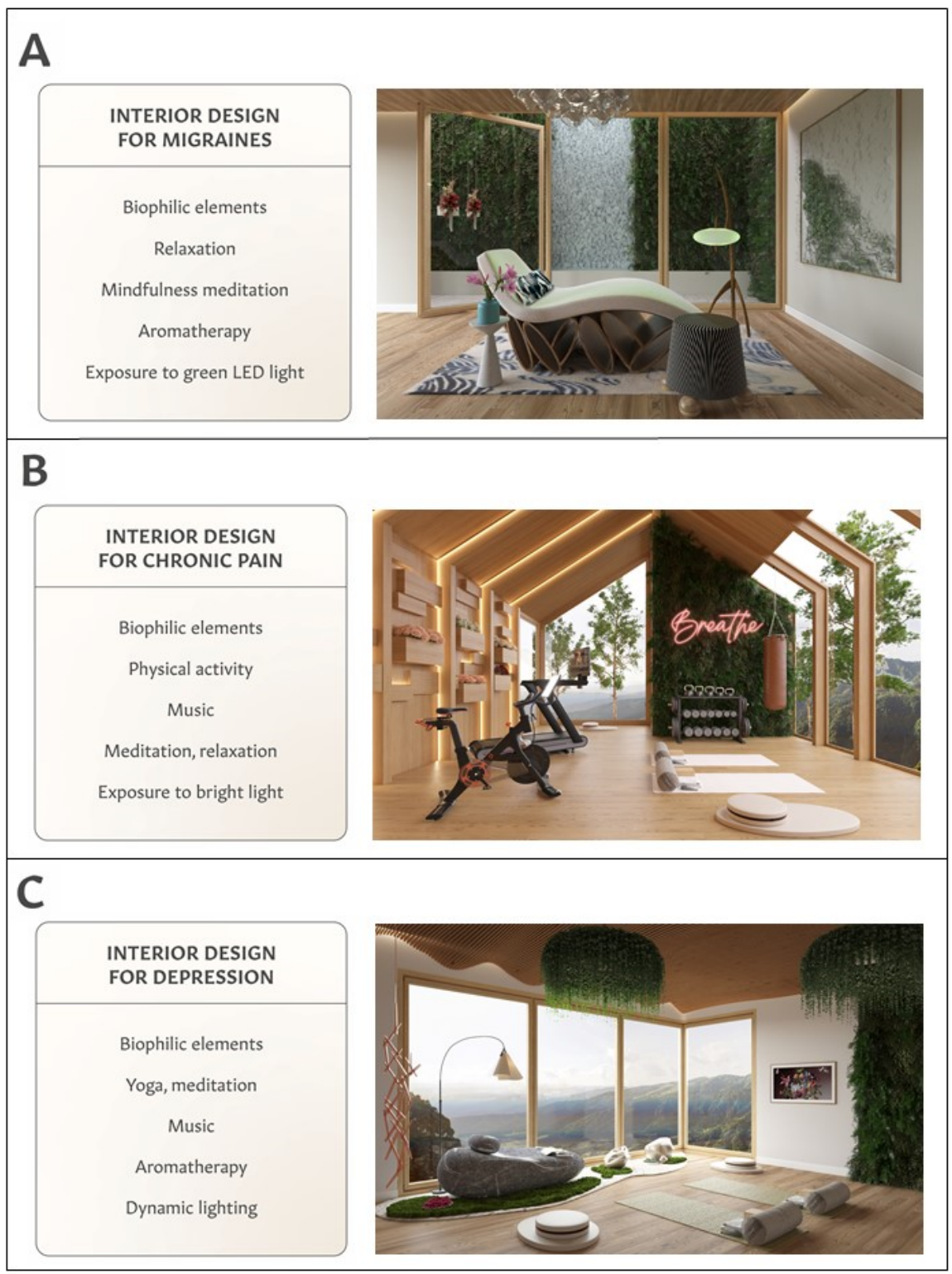

Figure 2. Designing therapeutic interior environments for people with migraines (A), chronic pain (B) and depression (C). Disease-specific interior designs are based on studies summarized in Tables 1-3. 


\subsection{Designing Therapeutic Interior Environments for People with Migraines}

Migraines are one of the most prevalent chronic diseases associated with significant disability. Among diverse precipitating factors for migraines, stress is considered the top trigger [62]. Recent reviews on non-pharmacological self-management of migraines suggest that several self-care modalities can reduce pain intensity and headache-related disability [63]. Lifestyle recommendations for people with migraines include stress management and sleep hygiene [64]. Table 1 summarizes the rationale for integrating diverse modalities, which can directly and/or indirectly provide health benefits for people living with migraines. Combining biophilic design with additional interior features fostering relaxation can lead to lower stress levels, thus supporting migraine prophylaxis. Exposure to green LED light and aromatherapy with lavender essential oils may lead to a reduction in headache frequency and severity $[65,66]$. The mechanisms by which lavender essential oil may improve a migraine include the inhibition of neurogenic inflammation, [66] and promoting relaxation and stress reduction [67-69].

Table 1. Research evidence on incorporating biophilic interventions and self-care modalities into therapeutic interior environments for people with migraines.

\begin{tabular}{ll}
\hline Modality & Studies Supporting Interior Landscapes Integrating Biophilic Interventions and Self-Care \\
\hline & - Exposure to houseplants and flowers can improve relaxation and reduce stress [51-56] \\
- Viewing nature indoors promotes relaxation [57] & Biophilic interventions can reduce stress [58] \\
Exposure to nature & - Touching white oak wood increases relaxation and calms prefrontal cortex activities [59,60] \\
& - Exposure to outdoor nature can reduce psychophysiological stress [70-72] \\
& - Nature exposure can reduce both perceived and physiological stress [73]
\end{tabular}

\section{Green LED light $\quad$ - Exposure to green LED light significantly decreases headache days in migraine patients [65]}

Aromatherapy

- $\quad$ Aromatherapy with lavender significantly reduces headache severity in migraine patients [74]

- Inhalation of peppermint essential oil reduces the intensity and frequency of headaches [75]

Relaxation - Relaxation training improves headache frequency and pain severity [76]

and mindfulness $\quad$ - Mindfulness-based stress reduction decreases migraine days [77]

meditation

- Mindfulness can improve headache-related disabilities and well-being [78]

- $\quad$ Relaxation and mindfulness meditation are suggested for migraine prophylaxis [79]

Yoga $\quad$ - Yoga practice reduces headache frequency and intensity in migraine patients [80]

Sleep hygiene

- $\quad$ Sleep disorders are associated with more frequent and severe migraines [81]

- $\quad$ Behavioral sleep treatment can reduce headache frequency and intensity $[82,83]$

As illustrated in Figure 2A, the customized interior design for people with migraines includes biophilic elements and features supporting migraine self-care. Ambient conditions are complex and varied, but familiar and comfortable. Sounds, smells and textures remind one of being outside in nature. All elements are intended to bring about a feeling of relaxation and calm. The biophilic elements consist of dynamic lighting, plants, fresh flowers, biomorphic and fractal shapes, a water-scape, the judicious use of wood and high-quality air filtration. While not shown, an addition of the Frame Smart TV (Samsung ${ }^{\circledR}$ ) would provide nature-inspired art, music and opportunities for guided meditation. Features supporting migraine self-care include an LED lamp delivering both green light and aromatherapy, as well as a comfortable lounge chair supporting meditation, relaxation and stress reduction. 
Varied and dynamic lighting - a biophilic aspect—is appointed in this case to accommodate a person with migraines' specific light sensitivities; for example, dimmable lighting, indirect natural lighting opportunities and ambient cove lighting. The combination of these lighting applications adds to the sense of calm, relaxation and tranquility reminiscent of the indirect qualities of a natural environment. Plants and fresh flowers are applied as additional biophilic elements to support relaxation and positive emotions $[55,56,87]$.

\subsection{Designing Therapeutic Interior Environments for People with Chronic Pain}

Chronic pain is a debilitating disorder, leading to disability and a reduced health-related quality of life. Chronic pain conditions include lower back pain, arthritis pain, cancer pain and neuropathic pain, as well as complex syndromes, such as fibromyalgia. Lifestyle (physical activity, nutrition and smoking) is associated with chronic pain $[88,89]$. Non-pharmacological modalities for pain management and relief may include physical therapy, yoga, mindfulness meditation, listening to music, sleep hygiene and nature therapy (Table 2). The American College of Physicians recommends physical exercises and yoga as a first-line therapy for lower back pain [90]. It is noteworthy that perioperative exposure to music is associated with the reduced intake of analgesic drugs [91,92]. There is also a growing number of studies indicating that exposure to nature and natural light may provide analgesia and reduce the burden of pain $[42,93]$.

Table 2. Clinical evidence on incorporating nature exposure and self-care modalities into therapeutic interior environments for people with chronic pain.

\begin{tabular}{ll}
\hline Modality & \multicolumn{2}{l}{ Studies Supporting Interior Landscapes Integrating Biophilic Interventions and Self-Care } \\
\hline & - Exposure to flowers can improve fibromyalgia pain and postoperative pain [43,44] \\
Exposure to nature & - Forest bathing can reduce posterior neck pain [42] \\
& - Forest bathing can reduce chronic pain and depressive symptoms, while also increasing natural \\
& killer (NK) cell activity [49]
\end{tabular}

- $\quad$ Exposure to natural sunlight can reduce pain and use of analgesic medications [61]

Lighting - Exposure to morning bright light can reduce lower back pain [94,95]

- $\quad$ Exposure to home-based morning bright light can improve fibromyalgia pain sensitivity [96]

- $\quad$ Exposure to green LED light can reduce pain in fibromyalgia patients [97]

$\begin{array}{ll} & \text { - Music can reduce chronic pain and the use of pain medications }[39,91,92] \\ \text { Music } & \text { Music significantly reduces postoperative pain }[92,98] \\ & \text { - Music reduces pain in fibromyalgia patients [99] }\end{array}$

Physical activity, yoga and breathing exercises

\begin{tabular}{lll}
\hline $\begin{array}{l}\text { Mindfulness } \\
\text { meditation }\end{array}$ & - & Mindfulness meditation can significantly reduce chronic pain and depressive symptoms [101,102] \\
\hline Sleep hygiene & $\bullet$ & Poor sleep quality is associated with increased pain intensity [103,104] \\
\hline $\begin{array}{l}\text { Combination of } \\
\text { modalities }\end{array}$ & - A combination of nature exposure, physical activity, education and social support can improve pain \\
and fatigue in fibromyalgia patients [105] & $\begin{array}{l}\text { A combination of music, relaxation and guided imagery reduces pain in fibromyalgia patients } \\
{[106,107]} \\
\text { Exercise and meditation reduces lower back pain intensity [108] }\end{array}$ \\
\hline
\end{tabular}


The therapeutic interior design concept for people with chronic pain includes biophilic elements and features supporting chronic pain self-care (Figure 2B). One of the key features is the room's natural light and focus on natural surroundings; for example, shade trees with a vista to foster a connection with nature. Other biophilic features consist of natural woods, indoor plants, biomorphic shapes and fresh flowers. The architectural design mimics symmetry and the use of repeating patterns as found in basic nature structures. Artificial smart lighting supports natural circadian rhythm cycles.

A room that provides the opportunity for, and encouragement of, exercise fosters the self-management of chronic diseases. Physical activities are supported by the presence of exercise and wellness equipment while facing a natural landscape and vista, thus integrating exercise and exposure to nature. Multiple yoga mats foster stretching and yoga practice with a companion, bridging physical activity and social support. To enrich this therapeutic environment, an integrated sound system serves as a high-quality music delivery system. Direct sunlight is an important part of designing for chronic pain, while providing exposure to nature and a vantage point can lead to faster stress recovery [109]. The design also includes ambient lighting that holds the capacity to emulate the blue light of the morning sun, and the yellow light of the evening sun, as well as narrow-band green LED light, shown to reduce pain in people with fibromyalgia [97].

\subsection{Designing Therapeutic Interior Environments for People with Depression}

Depression is a chronic mental disorder for which antidepressant and behavioral therapies have limited efficacy [110]. Depression is often comorbid with other chronic diseases, including chronic pain and neurodegenerative disorders. Living with depression is associated with increased disability and suicide risk [111,112]. Lifestyle medicine for depression includes nutrition, physical exercise and recreation, relaxation and meditation, sleep quality and social support [113]. As summarized in Table 3, there are multiple self-care modalities which can clinically benefit people living with depression. Positive effects of exposure to nature on mental health and well-being are well established [114,115]. The mechanisms by which exposure to nature can modulate affective states include stress reduction and the improvement of cognitive functions [116]. Bright light therapy has been effective in treating depression, including bipolar depression [117]. Recent reviews and meta-analysis studies support listening to music as an effective non-pharmacological intervention for depression [37,38]. Based on the beneficial effects of exposure to nature and self-care modalities (Table 3), we suggest designing an interior environment that would support emotional regulation by increasing both arousal and valence with visual and acoustic stimulation.

Table 3. Clinical evidence on incorporating nature exposure and self-care modalities into therapeutic interior environments for people with depression.

\begin{tabular}{ll}
\hline Modality & Studies Supporting Interior Landscapes Integrating Biophilic Interventions and Self-Care \\
\hline & - Exposure to outdoor nature can reduce depression [41,71] \\
& - Green space view from a window can reduce risk of depression [118] \\
Exposure to nature & - Exposure to green spaces can affect mental health and well-being [119] \\
& - Exposure to flowers can reduce depressive symptoms in fibromyalgia patients [44] \\
& - Exposure to natural environments increases positive affect and decreases negative affect [120,121]
\end{tabular}

Lighting

- $\quad$ Bright light therapy is effective for non-seasonal depression and bipolar depression $[117,122,123]$

- $\quad$ Bright light therapy is effective for people with seasonal affective disorder [124,125]

- $\quad$ Blue-wavelength light therapy can be effective in treating depression [126] 
Table 3. Cont.

\begin{tabular}{lll}
\hline Modality & Studies Supporting Interior Landscapes Integrating Biophilic Interventions and Self-Care \\
\hline $\begin{array}{l}\text { Physical activity and } \\
\text { yoga }\end{array}$ & - & $\begin{array}{l}\text { Physical activity can reduce depressive symptoms [127-129] } \\
\text { Yoga can reduce depressive symptoms [130] }\end{array}$ \\
\hline $\begin{array}{l}\text { Mindfulness } \\
\text { meditation }\end{array}$ & - & Mindfulness meditation can improve depressive symptoms [131,132] \\
\hline Breathing exercises & - & $\begin{array}{l}\text { Breathing exercises reduce depressive symptoms in patients with major depressive disorder who } \\
\text { did not respond to antidepressant medications [133] } \\
\text { Breathing exercises can reduce depressive symptoms [134,135] }\end{array}$ \\
\hline Aromatherapy & - & Aromatherapy can improve depressive symptoms [136] \\
\hline Sleep hygiene & - & $\begin{array}{l}\text { People with insomnia have a higher risk for developing depression [137] } \\
\text { Altering circadian rhythms can be linked to major depression [138] }\end{array}$ \\
\hline Nutrition & - & $\begin{array}{l}\text { Supplementation with St John's Wort has significant clinical efficacy in reducing depressive } \\
\text { symptoms, including people living with major depressive disorder [139,140] } \\
\text { Mediterranean diet is associated with a lower risk for depression [141] }\end{array}$ \\
\hline
\end{tabular}

Figure 2C summarizes suggested interior design features for people living with depression. These include biophilic elements such as a fractal ceiling, indoor plants, fresh flower art, natural wood, a biomorphic floor lamp, and floor-to-ceiling windows overlooking a natural landscape and providing direct sunlight. Interior features fostering self-care practices include meditation space, yoga mats, an integrated diffuser in a floor lamp for aromatherapy, and the Frame Smart TV (Samsung ${ }^{\circledR}$ ) as a delivery system of music, guided meditations and nature-inspired art. All biophilic and other design features encourage relaxation and stress reduction, which can mitigate depressive symptoms [142]. Dynamic lighting for this purpose includes natural bright light, provided by large windows, and cove lighting surrounding the space, for ambient lighting effects that can provide bright light year-round. Two yoga mats are placed to encourage yoga practice and stretching exercises with a companion, thus simultaneously providing social support.

\section{Expanding Interior Design Elements for Therapeutic Purposes}

As shown in Figure 2, renderings of therapeutic interior environments emphasize diverse biophilic elements delivered via natural light (through windows and a smart lighting system), the presence of indoor plants and fresh flowers, fractals, soundscapes, biomorphic shapes, natural materials and colors, and vista viewpoints. In addition, the design of therapeutic spaces for people with migraines, chronic pain or depression (Figure 2), can include the incorporation of such indoor features as the Frame Smart TV (Samsung ${ }^{\circledR}$ ) and a smart lighting system, which can provide the benefits of nature therapy, music therapy and light therapy. Using the Frame Smart TV to provide both biophilic art and a high-quality sound system for music and guided meditation offers innovative ways to expand the application of a TV set as a delivery system of therapies for pain or depression [37-39,91,92,98]. Currently, such frame TV models are marketed for their abilities to serve as a standard TV or as décor to display art, when in the "off" position.

Another example of expanding the applications of interior features is to use lighting systems for light therapy purposes. Light therapy has been recognized as treatment for depression or fatigue $[123,143,144]$, while recent studies suggest that specific LED light conditions can provide clinical benefits for people living with migraines, fibromyalgia and chronic pain ([145] and references in Tables 1 and 2). Specific in-home lighting conditions were used for the treatment of fatigue in people with traumatic brain injury $[146,147]$. Effects of light exposure on sleep quality are well documented [148,149], while there are direct correla- 
tions between the quality of sleep and diverse health conditions [34,35,103,150]. Therefore, lighting conditions which promote sleep hygiene may provide additional health benefits for people living with migraines, insomnia, fibromyalgia, chronic pain or depression.

Rapid advancements in the smart LED lighting systems allow a user to program bright light in the morning to reduce pain, depression and fatigue, or provide green LED light therapy for a reduction in migraine headaches. Currently, health-related light bulbs include those with: (1) eliminated, or reduced, blue color wavelength light, which are marketed as "circadian rhythms bulbs", "no blue", "low blue", "zero blue" or "restful bedtime bulb", (2) green LED light, marketed as "migraine relief LED light" or "green light for migraine sufferers" by Allay Lamp ${ }^{\circledR}$, and (3) natural light, marketed as "natural sunlight", "natural daylight light" or "full-spectrum sunlight like". Such diverse LED technologies are commercially available as "stand alone" bulbs, or as an integrated, smart lighting system, thus facilitating the custom design of lighting within biophilic interior design environments for people with specific medical conditions.

\section{Advancing Therapeutic Interior Design to Improve Healthcare Outcomes}

With the number of people living with chronic diseases increasing worldwide, there are ongoing needs to innovate and to expand disease prevention and treatments. As illustrated in Figure 3A, creating therapeutic indoor environments is applicable not only to residential homes, but also for hospital rooms, assisted-living facilities and hospital at home $(\mathrm{HaH})$ programs [151]. While biophilic design has been recognized by healthcare facilities [22,152-155] and assisted-living housing [156], there are no reports of applying health-related interior design for HaH care. The COVID-19 pandemic has renewed an interest in home care services $[157,158]$; therefore, therapeutic interior design for HaH may offer additional clinical benefits. An example of interior design features for an $\mathrm{HaH}$ setting could include biophilic elements, a smart lighting system, and soundscapes delivering relaxing music (Figure 3B). Since the judicious design of lighting can improve quality of sleep, fatigue, depression, migraine headaches and chronic pain, while listening to music can reduce pain and depressive symptoms, these two interior elements alone can provide clinical benefits for people with cancer, COPD and other medical conditions, which are preferred when considering $\mathrm{HaH}$ care.

A

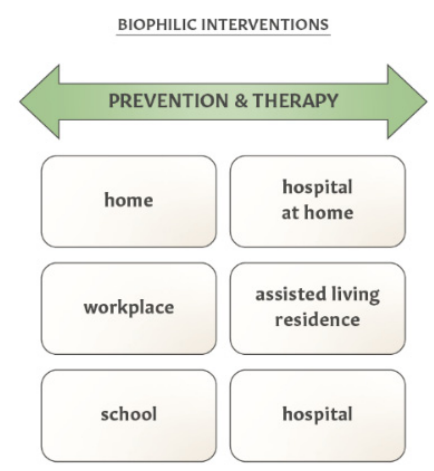

B

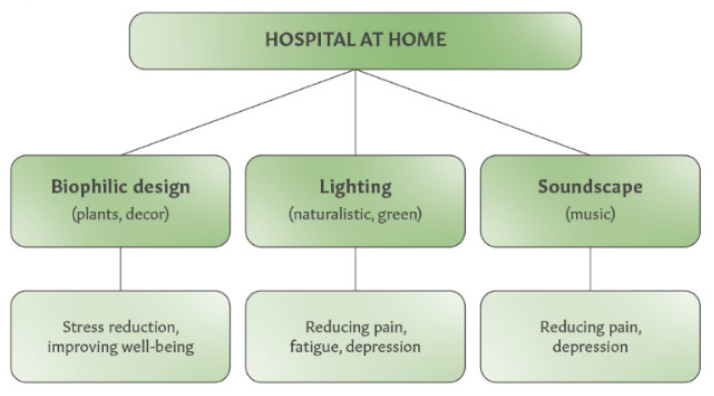

Figure 3. Applications of biophilic interventions and health-related interior landscapes in diverse indoor environments. (A) Examples of diverse indoor environments amenable to health-related interior design. (B) Examples of therapeutic interior design elements and their clinical benefits for hospital at home care.

In the U.S. alone, the design of disease-specific therapeutic environments could benefit a significant portion of the 330 million people living in 128 million households. To this end, the Biophilic Design Matrix has been proposed to facilitate the implementation of biophilic attributes by interior designers [22,159,160]. Future prospects for therapeutic interior environments can also include integration with digital health technologies for migraines [161,162], chronic pain [163,164] and depression [165,166]. It is appealing to 
suggest that integrated healthcare systems such as Sanford Health, Kaiser Permanente, Intermountain Healthcare, Trinity Health and others may consider partnerships with architectural firms and interior design companies to create, validate and implement residential and commercial interior environments for people living with diverse chronic diseases.

We acknowledge the limitations of this viewpoint article, which include diverse levels of evidence to support therapeutic interior design, thus being prone to publication bias. Recent review articles on biophilic design point out research gaps on the relationships between biophilic attributes and health-related outcomes $[9,13,16,17,24,160]$. To the best of our knowledge, there are only a few reports on combining biophilic interventions with pharmacotherapies [43,61]. With respect to studies on self-care for specific chronic diseases, we include references on systematic review and meta-analysis (SR/MA) when available; however, given the diversity of research evidence for biophilic interventions and individual self-care modalities (ranging from small-group observational and pilot studies, longitudinal studies, narrative reviews, RCTs and SR/MA), presenting such a cross-disciplinary topic as an SR/MA would be difficult at the present time. We emphasize an ongoing need for more research and development projects to evaluate the efficacy and effectiveness of therapeutic interior environments and disease-specific self-care for people living with migraines, chronic pain, depression and other chronic diseases.

\section{Conclusions}

Despite a recognition of the benefits of biophilic design by healthcare facilities, transforming residential indoor spaces into therapeutic environments receives relatively less attention. In this viewpoint article, we discuss the integration of biophilic interventions with indoor features fostering self-care for people living with migraines, chronic pain and depression. We conclude that therapeutic interior design supporting a connection with nature, healthy lifestyle and disease-specific self-care practices offers unique opportunities to improve healthcare outcomes in residential applications and beyond.

Author Contributions: D.D.H. and G.B. conceived this project and wrote the manuscript. G.B. performed the literature review and analysis. D.D.H. designed therapeutic interior environments. All authors have read and agreed to the published version of the manuscript.

Funding: This project was performed without external funding.

Institutional Review Board Statement: Not applicable.

Informed Consent Statement: Not applicable.

Data Availability Statement: Not applicable.

Acknowledgments: We thank Danielle Alling from Ritual Made, LLC for her assistance with figure preparations, and Uros Strugulc for his assistance with preparing renderings. We are grateful to Jade Huntsman and Lily Huntsman for critical reading of early versions of the manuscript and helpful comments.

Conflicts of Interest: D.D.H. is a founder and owner of Dayhouse Studio, an interior design company. G.B. is a founder and owner of OMNI Self-care, LLC, a health-branding company creating digital content for disease self-management, self-care and health promotion.

\section{References}

1. James, S.L.; Abate, D.; Abate, K.H.; Abay, S.M.; Abbafati, C.; Abbasi, N.; Abbastabar, H.; Abd-Allah, F.; Abdela, J.; Abdelalim, A.; et al. Global, regional, and national incidence, prevalence, and years lived with disability for 354 diseases and injuries for 195 countries and territories, 1990-2017: A systematic analysis for the Global Burden of Disease Study 2017. Lancet 2018, 392, 1789-1858. [CrossRef]

2. $\quad$ Feigin, V.L.; Vos, T.; Nichols, E.; Owolabi, O.M.; Carroll, W.M.; Dichgans, M.; Deuschl, G.; Parmar, P.; Brainin, M.; Murray, C. The global burden of neurological disorders: Translating evidence into policy. Lancet Neurol. 2019, 19, 255-265. [CrossRef]

3. Booth, F.W.; Roberts, C.K.; Thyfault, J.P.; Ruegsegger, G.N.; Toedebusch, R.G. Role of Inactivity in Chronic Diseases: Evolutionary Insight and Pathophysiological Mechanisms. Physiol. Rev. 2017, 97, 1351-1402. [CrossRef] 
4. Brasche, S.; Bischof, W. Daily time spent indoors in German homes-Baseline data for the assessment of indoor exposure of German occupants. Int. J. Hyg. Environ. Health 2005, 208, 247-253. [CrossRef]

5. Pears, M.; Kola-Palmer, S.; De Azevedo, L.B. The impact of sitting time and physical activity on mental health during COVID-19 lockdown. Sport Sci. Health 2021, 1-13. [CrossRef]

6. Manger, S. Lifestyle interventions for mental health. Aust. J. Gen. Pr. 2019, 48, 670-673. [CrossRef]

7. Dean, E.; Söderlund, A. What is the role of lifestyle behaviour change associated with non-communicable disease risk in managing musculoskeletal health conditions with special reference to chronic pain? BMC Musculoskelet. Disord. 2015, 16, 1-7. [CrossRef]

8. Bulaj, G.; Clark, J.; Ebrahimi, M.; Bald, E. From Precision Metapharmacology to Patient Empowerment: Delivery of Self-Care Practices for Epilepsy, Pain, Depression and Cancer Using Digital Health Technologies. Front. Pharmacol. 2021, 12. [CrossRef]

9. Yassein, G.; Ebrahiem, S. Biophilic Design in the Built Environment to Improve Well-Being: A Systematic Review of Practices. J. Urban Res. 2018, 30, 128-146. [CrossRef]

10. Wilson, E.O. Biophilia; Harvard University Press: Cambridge, MA, USA, 1984.

11. Kellert, S.R.; Calabrese, E.F. The Practice of Biophilic Design; Terrapin Bright LLC: London, UK, 2015. Available online: https: //www.biophilic-design.com/ (accessed on 12 February 2022).

12. Kellert, S.R.; Heerwagen, J.; Mador, M. Biophilic Design: The Theory, Science, and Practice of Bringing Buildings to Life; Wiley \& Sons: New York, NY, USA; Hoboken, NJ, USA, 2008.

13. Gillis, K.; Gatersleben, B. A Review of Psychological Literature on the Health and Wellbeing Benefits of Biophilic Design. Buildings 2015, 5, 948-963. [CrossRef]

14. Taylor, R. The Potential of Biophilic Fractal Designs to Promote Health and Performance: A Review of Experiments and Applications. Sustainability 2021, 13, 823. [CrossRef]

15. Zhong, W.; Schröder, T.; Bekkering, J. Biophilic design in architecture and its contributions to health, well-being, and sustainability: A critical review. Front. Arch. Res. 2021. [CrossRef]

16. Thomas, C.; Xing, Y. To What Extent Is Biophilia Implemented in the Built Environment to Improve Health and Wellbeing?State-of-the-Art Review and a Holistic Biophilic Design Framework. Emerg. Res. Sustain. Energy Build. A Low-Carbon Future 2021, 227-247. [CrossRef]

17. Hung, S.-H.; Chang, C.-Y. Health benefits of evidence-based biophilic-designed environments: A review. J. People Plants Environ. 2021, 24, 1-16. [CrossRef]

18. Barbiero, G.; Berto, R. Biophilia as Evolutionary Adaptation: An Onto- and Phylogenetic Framework for Biophilic Design. Front. Psychol. 2021, 12. [CrossRef]

19. McSweeney, J.; Rainham, D.; Johnson, S.A.; Sherry, S.B.; Singleton, J. Indoor nature exposure (INE): A health-promotion framework. Health Promot. Int. 2014, 30, 126-139. [CrossRef]

20. Yin, J.; Yuan, J.; Arfaei, N.; Catalano, P.J.; Allen, J.G.; Spengler, J.D. Effects of biophilic indoor environment on stress and anxiety recovery: A between-subjects experiment in virtual reality. Environ. Int. 2019, 136, 105427. [CrossRef]

21. McSweeney, J.; Johnson, S.; Sherry, S.; Singleton, J.; Rainham, D. Indoor nature exposure and influence on physiological stress markers. Int. J. Environ. Health Res. 2019, 1-15. [CrossRef]

22. McGee, B.; Marshall-Baker, A. Loving Nature From the Inside Out. HERD Health Environ. Res. Des. J. 2015, 8, 115-130. [CrossRef]

23. Gray, T.; Birrell, C. Are Biophilic-Designed Site Office Buildings Linked to Health Benefits and High Performing Occupants? Int. J. Environ. Res. Public Health 2014, 11, 12204-12222. [CrossRef]

24. Khanehshenas, F.; Habibi, P.; Zakerian, S.A. The Effect of Biophilic Design Patterns on Employee's Health and Well-being: A Systematic Review. J. Ergon. 2020, 7, 1-11. [CrossRef]

25. Peters, T.; Verderber, S. Biophilic Design Strategies in Long-Term Residential Care Environments for Persons with Dementia. J. Aging Environ. 2021, 1-29. [CrossRef]

26. Nuamah, J.; Rodriguez-Paras, C.; Sasangohar, F. Veteran-Centered Investigation of Architectural and Space Design Considerations for Post-Traumatic Stress Disorder (PTSD). HERD: Heal. Environ. Res. Des. J. 2020, 14, 164-173. [CrossRef]

27. Norouzi, N.; Garza, C.M. Architecture for Children With Autism Spectrum Disorder and Their Therapists. HERD Health Environ. Res. Des. J. 2021, 14, 147-156. [CrossRef]

28. Lattacher, S.L.; Wohofsky, L.; Scharf, P.; Krainer, D. A Customized Smart Home and Interior Design Concept Co-Designed with and for People with Autism Spectrum Disorder. In Navigating Healthcare through Challenging Times; IOS Press: Amsterdam, The Netherlands, 2021; Volume 279, pp. 36-37. [CrossRef]

29. Shin, J.-H.; Dennis, J.S.; Mohammed, H. Mental Health Outcome Measures in Environmental Design Research: A Critical Review. HERD: Health Environ. Res. Des. J. 2021, 14, 331-357. [CrossRef]

30. Engineer, A.; Sternberg, E.M.; Najafi, B. Designing Interiors to Mitigate Physical and Cognitive Deficits Related to Aging and to Promote Longevity in Older Adults: A Review. Gerontology 2018, 64, 612-622. [CrossRef]

31. Lee, Y.; Park, J.; Jang, M. Perceived effects of home renovation on independence of physically disabled Koreans living at home. Disabil. Rehabil. 2017, 40, 2380-2387. [CrossRef]

32. Capasso, L.; D'Alessandro, D. Housing and health: Here we go again. Int. J. Environ. Res. Public Health 2021, 18, 12060. [CrossRef]

33. Besedovsky, L.; Lange, T.; Haack, M. The Sleep-Immune Crosstalk in Health and Disease. Physiol. Rev. 2019, 99, 1325-1380. [CrossRef] 
34. Goldstein, A.N.; Walker, M.P. The Role of Sleep in Emotional Brain Function. Annu. Rev. Clin. Psychol. 2014, 10, 679-708. [CrossRef] [PubMed]

35. Tiseo, C.; Vacca, A.; Felbush, A.; Filimonova, T.; Gai, A.; Glazyrina, T.; Hubalek, I.A.; Marchenko, Y.; Overeem, L.H.; Piroso, S.; et al. Migraine and sleep disorders: A systematic review. J. Headache Pain 2020, 21, 1-13. [CrossRef] [PubMed]

36. Yin, J.; Jin, X.; Shan, Z.; Li, S.; Huang, H.; Li, P.; Peng, X.; Peng, Z.; Yu, K.; Bao, W.; et al. Relationship of Sleep Duration With All-Cause Mortality and Cardiovascular Events: A Systematic Review and Dose-Response Meta-Analysis of Prospective Cohort Studies. J. Am. Heart Assoc. 2017, 6, e005947. [CrossRef] [PubMed]

37. Leubner, D.; Hinterberger, T. Reviewing the Effectiveness of Music Interventions in Treating Depression. Front. Psychol. 2017, 8, 1109. [CrossRef]

38. Tang, Q.; Huang, Z.; Zhou, H.; Ye, P. Effects of music therapy on depression: A meta-analysis of randomized controlled trials. PLoS ONE 2020, 15, e0240862. [CrossRef]

39. Garza-Villarreal, A.E.; Pando, V.; Vuust, P.; Parsons, C. Music-Induced Analgesia in Chronic Pain Conditions: A Systematic Review and Meta-Analysis. Pain Physician 2017, 20, 597-610. [CrossRef] [PubMed]

40. Martin-Saavedra, J.S.; Vergara-Mendez, L.D.; Pradilla, I.; Vélez-Van-Meerbeke, A.; Talero-Gutiérrez, C. Standardizing music characteristics for the management of pain: A systematic review and meta-analysis of clinical trials. Complement. Ther. Med. 2018, 41,81-89. [CrossRef]

41. Sahlin, E.; Ahlborg, J.G.; Tenenbaum, A.; Grahn, P. Using Nature-Based Rehabilitation to Restart a Stalled Process of Rehabilitation in Individuals with Stress-Related Mental Illness. Int. J. Environ. Res. Public Health 2015, 12, 1928-1951. [CrossRef]

42. Kang, B.; Kim, T.; Kim, M.J.; Lee, K.H.; Choi, S.; Lee, N.H.; Kim, H.R.; Jun, B.; Park, S.Y.; Lee, S.J.; et al. Relief of Chronic Posterior Neck Pain Depending on the Type of Forest Therapy: Comparison of the Therapeutic Effect of Forest Bathing Alone Versus Forest Bathing With Exercise. Ann. Rehabil. Med. 2015, 39, 957-963. [CrossRef]

43. Park, S.-H.; Mattson, R.H. Ornamental Indoor Plants in Hospital Rooms Enhanced Health Outcomes of Patients Recovering from Surgery. J. Altern. Complement. Med. 2009, 15, 975-980. [CrossRef]

44. Yavne, Y.; Kabaha, A.; Rosen, T.; Avisar, I.; Orbach, H.; Amital, D.; Amital, H. The Powers of Flowers: Evaluating the Impact of Floral Therapy on Pain and Psychiatric Symptoms in Fibromyalgia. Israel Med. Assoc. J. IMAJ 2019, 21, 449-453.

45. Kim, H.; Kim, J.; Ju, H.J.; Jang, B.J.; Wang, T.K.; Kim, Y.I. Effect of Forest Therapy for Menopausal Women with Insomnia. Int. J. Environ. Res. Public Health 2020, 17, 6548. [CrossRef]

46. Shin, J.C.; Parab, K.V.; An, R.; Grigsby-Toussaint, D.S. Greenspace exposure and sleep: A systematic review. Environ. Res. 2019, 182, 109081. [CrossRef] [PubMed]

47. Kakar, E.; Venema, E.; Jeekel, J.; Klimek, M.; van der Jagt, M. Music intervention for sleep quality in critically ill and surgical patients: A meta-analysis. BMJ Open 2021, 11, e042510. [CrossRef] [PubMed]

48. Feng, F.; Zhang, Y.; Hou, J.; Cai, J.; Jiang, Q.; Li, X.; Zhao, Q.; Li, B.-A. Can music improve sleep quality in adults with primary insomnia? A systematic review and network meta-analysis. Int. J. Nurs. Stud. 2018, 77, 189-196. [CrossRef]

49. Han, J.-W.; Choi, H.; Jeon, Y.-H.; Yoon, C.-H.; Woo, J.-M.; Kim, W. The Effects of Forest Therapy on Coping with Chronic Widespread Pain: Physiological and Psychological Differences between Participants in a Forest Therapy Program and a Control Group. Int. J. Environ. Res. Public Health 2016, 13, 255. [CrossRef] [PubMed]

50. Chanda, M.L.; Levitin, D.J. The neurochemistry of music. Trends Cogn. Sci. 2013, 17, 179-193. [CrossRef] [PubMed]

51. Deng, L.; Deng, Q. The basic roles of indoor plants in human health and comfort. Environ. Sci. Pollut. Res. 2018, 25, 36087-36101. [CrossRef]

52. Dijkstra, K.; Pieterse, M.; Pruyn, A. Stress-reducing effects of indoor plants in the built healthcare environment: The mediating role of perceived attractiveness. Prev. Med. 2008, 47, 279-283. [CrossRef]

53. Jiang, S.; Deng, L.; Luo, H.; Li, X.; Guo, B.; Jiang, M.; Jia, Y.; Ma, J.; Sun, L.; Huang, Z. Effect of Fragrant Primula Flowers on Physiology and Psychology in Female College Students: An Empirical Study. Front. Psychol. 2021, 12, 437. [CrossRef]

54. Song, C.; Igarashi, M.; Ikei, H.; Miyazaki, Y. Physiological effects of viewing fresh red roses. Complement. Ther. Med. 2017, 35, 78-84. [CrossRef]

55. Ikei, H.; Komatsu, M.; Song, C.; Himoro, E.; Miyazaki, Y. The physiological and psychological relaxing effects of viewing rose flowers in office workers. J. Physiol. Anthr. 2014, 33, 6. [CrossRef] [PubMed]

56. Mochizuki-Kawai, H.; Matsuda, I.; Mochizuki, S. Viewing a flower image provides automatic recovery effects after psychological stress. J. Environ. Psychol. 2020, 70, 101445. [CrossRef]

57. Jo, H.; Song, C.; Miyazaki, Y. Physiological Benefits of Viewing Nature: A Systematic Review of Indoor Experiments. Int. J. Environ. Res. Public Health 2019, 16, 4739. [CrossRef] [PubMed]

58. Yin, J.; Arfaei, N.; Macnaughton, P.; Catalano, P.J.; Allen, J.G.; Spengler, J.D. Effects of biophilic interventions in office on stress reaction and cognitive function: A randomized crossover study in virtual reality. Indoor Air 2019, 29, 1028-1039. [CrossRef] [PubMed]

59. Ikei, H.; Song, C.; Miyazaki, Y. Physiological Effects of Touching Wood. Int. J. Environ. Res. Public Health. 2017, 14, 801. [CrossRef]

60. Ikei, H.; Song, C.; Miyazaki, Y. Physiological Effects of Touching Coated Wood. Int. J. Environ. Res. Public Health 2017, 14, 773. [CrossRef]

61. Walch, J.M.; Rabin, B.S.; Day, R.; Williams, J.N.; Choi, K.; Kang, J.D. The Effect of Sunlight on Postoperative Analgesic Medication Use: A Prospective Study of Patients Undergoing Spinal Surgery. Psychosom. Med. 2005, 67, 156-163. [CrossRef] 
62. Peroutka, S.J. What Turns on a Migraine? A Systematic Review of Migraine Precipitating Factors. Curr. Pain Headache Rep. 2014, 18, 1-6. [CrossRef]

63. Probyn, K.; Bowers, H.; Mistry, D.; Caldwell, F.; Underwood, M.; Patel, S.; Sandhu, H.K.; Matharu, M.; Pincus, T.; On Behalf of the CHESS Team. Non-pharmacological self-management for people living with migraine or tension-type headache: A systematic review including analysis of intervention components. BMJ Open 2017, 7, e016670. [CrossRef]

64. Robblee, J.; Starling, A.J. SEEDS for success: Lifestyle management in migraine. Clevel. Clin. J. Med. 2019, 86, 741-749. [CrossRef]

65. Martin, L.F.; Patwardhan, A.M.; Jain, S.V.; Salloum, M.M.; Freeman, J.; Khanna, R.; Gannala, P.; Goel, V.; Jones-MacFarland, F.N.; Killgore, W.D.; et al. Evaluation of green light exposure on headache frequency and quality of life in migraine patients: A preliminary one-way cross-over clinical trial. Cephalalgia 2020, 41, 135-147. [CrossRef] [PubMed]

66. Yuan, R.; Zhang, D.; Yang, J.; Wu, Z.; Luo, C.; Han, L.; Yang, F.; Lin, J.; Yang, M. Review of aromatherapy essential oils and their mechanism of action against migraines. J. Ethnopharmacol. 2020, 265, 113326. [CrossRef] [PubMed]

67. Toda, M.; Matsuse, R. Endocrinological effect of lavender aromatherapy on stressful visual stimuli. Contemp. Clin. Trials Commun. 2020, 17, 100547. [CrossRef] [PubMed]

68. Donelli, D.; Antonelli, M.; Bellinazzi, C.; Gensini, G.F.; Firenzuoli, F. Effects of lavender on anxiety: A systematic review and meta-analysis. Phytomedicine 2019, 65, 153099. [CrossRef]

69. López, V.; Nielsen, B.; Solas, M.; Ramírez, M.J.; Jäger, A.K. Exploring Pharmacological Mechanisms of Lavender (Lavandula angustifolia) Essential Oil on Central Nervous System Targets. Front. Pharmacol. 2017, 8, 280. [CrossRef] [PubMed]

70. Antonelli, M.; Barbieri, G.; Donelli, D. Effects of forest bathing (shinrin-yoku) on levels of cortisol as a stress biomarker: A systematic review and meta-analysis. Int. J. Biometeorol. 2019, 63, 1117-1134. [CrossRef]

71. Stier-Jarmer, M.; Throner, V.; Kirschneck, M.; Immich, G.; Frisch, D.; Schuh, A. The Psychological and Physical Effects of Forests on Human Health: A Systematic Review of Systematic Reviews and Meta-Analyses. Int. J. Environ. Res. Public Health 2021, 18, 1770. [CrossRef]

72. Stigsdotter, U.K.; Corazon, S.S.; Sidenius, U.; Nyed, P.K.; Larsen, H.B.; Fjorback, L.O. Efficacy of nature-based therapy for individuals with stress-related illnesses: Randomised controlled trial. Br. J. Psychiatry 2018, 213, 404-411. [CrossRef]

73. Shuda, Q.; Bougoulias, M.E.; Kass, R. Effect of nature exposure on perceived and physiologic stress: A systematic review. Complement. Ther. Med. 2020, 53, 102514. [CrossRef]

74. Sasannejad, P.; Saeedi, M.; Shoeibi, A.; Gorji, A.; Abbasi, M.; Foroughipour, M. Lavender Essential Oil in the Treatment of Migraine Headache: A Placebo-Controlled Clinical Trial. Eur. Neurol. 2012, 67, 288-291. [CrossRef]

75. Hasanpour-Dehkordi, A.; Rafieian-Kopaei, M.; Lorigooini, Z.; Deris, F.; Solati, K.; Mahdiyeh, F. Comparing the effect of intranasal lidocaine $4 \%$ with peppermint essential oil drop $1.5 \%$ on migraine attacks: A double-blind clinical trial. Int. J. Prev. Med. 2019, 10, 121. [CrossRef] [PubMed]

76. D'Souza, P.J.; Lumley, M.A.; Kraft, C.A.; Dooley, J.A. Relaxation Training and Written Emotional Disclosure for Tension or Migraine Headaches: A Randomized, Controlled Trial. Ann. Behav. Med. 2008, 36, 21-32. [CrossRef] [PubMed]

77. Wells, R.E.; O'Connell, N.; Pierce, C.R.; Estave, P.; Penzien, D.B.; Loder, E.; Zeidan, F.; Houle, T.T. Effectiveness of Mindfulness Meditation vs Headache Education for Adults With Migraine. JAMA Intern. Med. 2021, 181, 317-328. [CrossRef] [PubMed]

78. Wells, R.E.; Seng, E.K.; Edwards, R.R.; Victorson, D.E.; Pierce, C.R.; Rosenberg, L.; Napadow, V.; Schuman-Olivier, Z. Mindfulness in migraine: A narrative review. Expert Rev. Neurother. 2020, 20, 207-225. [CrossRef] [PubMed]

79. Ha, H.; Gonzalez, A. Migraine headache prophylaxis. Am. Fam. Physician 2019, 99, 17-24. [PubMed]

80. Kumar, A.; Bhatia, R.; Sharma, G.; Dhanlika, D.; Vishnubhatla, S.; Singh, R.K.; Dash, D.; Tripathi, M.; Srivastava, M.P. Effect of yoga as add-on therapy in migraine (CONTAIN). Neurology 2020, 94, e2203-e2212. [CrossRef]

81. Rains, J.C. Sleep and Migraine: Assessment and Treatment of Comorbid Sleep Disorders. Headache J. Head Face Pain 2018, 58, 1074-1091. [CrossRef]

82. Smitherman, T.A.; Walters, A.B.; Davis, R.E.; Ambrose, C.E.; Roland, M.; Houle, T.; Rains, J.C. Randomized Controlled Pilot Trial of Behavioral Insomnia Treatment for Chronic Migraine With Comorbid Insomnia. Headache J. Head Face Pain 2016, 56, $276-291$. [CrossRef]

83. Calhoun, A.H.; Ford, S. Behavioral Sleep Modification May Revert Transformed Migraine to Episodic Migraine. Headache J. Head Face Pain 2007, 47, 1178-1183. [CrossRef]

84. Von Luckner, A.; Riederer, F. Magnesium in Migraine Prophylaxis-Is There an Evidence-Based Rationale? A Systematic Review. Headache J. Head Face Pain 2017, 58, 199-209. [CrossRef]

85. Kirkland, A.; Sarlo, G.L.; Holton, K.F. The Role of Magnesium in Neurological Disorders. Nutrients 2018, 10, 730. [CrossRef] [PubMed]

86. Maghbooli, M.; Golipour, F.; Esfandabadi, A.M.; Yousefi, M. Comparison Between the Efficacy of Ginger and Sumatriptan in the Ablative Treatment of the Common Migraine. Phytotherapy Res. 2013, 28, 412-415. [CrossRef] [PubMed]

87. Haviland-Jones, J.; Rosario, H.H.; Wilson, P.; McGuire, T.R. An Environmental Approach to Positive Emotion: Flowers. Evol. Psychol. 2005, 3. [CrossRef]

88. Micheletti, J.K.; Bláfoss, R.; Sundstrup, E.; Bay, H.; Pastre, C.M.; Andersen, L.L. Association between lifestyle and musculoskeletal pain: Cross-sectional study among 10,000 adults from the general working population. BMC Musculoskelet. Disord. 2019, 20, 1-8 [CrossRef] [PubMed] 
89. Yoshimoto, T.; Ochiai, H.; Shirasawa, T.; Nagahama, S.; Uehara, A.; Muramatsu, J.; Kokaze, A. Clustering of Lifestyle Factors and Its Association with Low Back Pain: A Cross-Sectional Study of Over 400,000 Japanese Adults. J. Pain Res. 2020, 13, 1411-1419. [CrossRef] [PubMed]

90. Qaseem, A.; Wilt, T.J.; McLean, R.M.; Forciea, M.A.; for the Clinical Guidelines Committee of the American College of Physicians. Noninvasive Treatments for Acute, Subacute, and Chronic Low Back Pain: A Clinical Practice Guideline from the American College of Physicians. Ann. Intern. Med. 2017, 166, 514-530. [CrossRef] [PubMed]

91. Fu, V.X.; Oomens, P.; Klimek, M.; Verhofstad, M.H.J.; Jeekel, J. The Effect of Perioperative Music on Medication Requirement and Hospital Length of Stay. Ann. Surg. 2019, 272, 961-972. [CrossRef]

92. Hole, J.; Hirsch, M.; Ball, E.; Meads, C. Music as an aid for postoperative recovery in adults: A systematic review and meta-analysis Lancet 2015, 386, 1659-1671. [CrossRef]

93. Stanhope, J.; Breed, M.F.; Weinstein, P. Exposure to greenspaces could reduce the high global burden of pain. Environ. Res. 2020, 187, 109641. [CrossRef]

94. Burns, J.W.; Gerhart, J.; Rizvydeen, M.; Kimura, M.; Burgess, H.J. Morning Bright Light Treatment for Chronic Low Back Pain: Potential Impact on the Volatility of Pain, Mood, Function, and Sleep. Pain Med. 2019, 21, 1153-1161. [CrossRef]

95. Burgess, H.J.; Rizvydeen, M.; Kimura, M.; Pollack, M.H.; Hobfoll, E.S.; Rajan, K.B.; Burns, J.W. An Open Trial of Morning Bright Light Treatment Among US Military Veterans with Chronic Low Back Pain: A Pilot Study. Pain Med. 2018, 20, 770-778. [CrossRef] [PubMed]

96. Burgess, H.J.; Park, M.; Ong, J.C.; Shakoor, N.; Williams, D.A.; Burns, J. Morning Versus Evening Bright Light Treatment at Home to Improve Function and Pain Sensitivity for Women with Fibromyalgia: A Pilot Study. Pain Med. 2016, 18, 116-123. [CrossRef]

97. Martin, L.; Porreca, F.; Mata, E.I.; Salloum, M.; Goel, V.; Gunnala, P.; Killgore, W.D.S.; Jain, S.; Jones-MacFarland, F.N.; Khanna, R.; et al. Green Light Exposure Improves Pain and Quality of Life in Fibromyalgia Patients: A Preliminary One-Way Crossover Clinical Trial. Pain Med. 2021, 22, 118-130. [CrossRef] [PubMed]

98. Lin, C.; Hwang, S.; Jiang, P.; Hsiung, N. Effect of Music Therapy on Pain After Orthopedic Surgery-A Systematic Review and Meta-Analysis. Pain Pr. 2020, 20, 422-436. [CrossRef] [PubMed]

99. Garza-Villarreal, E.A.; Wilson, A.D.; Vase, L.; Brattico, E.; Barrios, F.A.; Jensen, T.S.T.; Romero-Romo, J.I.; Vuust, P. Music reduces pain and increases functional mobility in fibromyalgia. Front. Psychol. 2014, 5, 90. [CrossRef] [PubMed]

100. Anderson, B.E.; Bliven, K.C.H. The Use of Breathing Exercises in the Treatment of Chronic, Nonspecific Low Back Pain. J. Sport Rehabil. 2017, 26, 452-458. [CrossRef]

101. Hilton, L.; Hempel, S.; Ewing, B.A.; Apaydin, E.; Xenakis, L.; Newberry, S.; Colaiaco, B.; Maher, A.R.; Shanman, R.M.; Sorbero, M.E.; et al. Mindfulness Meditation for Chronic Pain: Systematic Review and Meta-analysis. Ann. Behav. Med. 2016, 51, 199-213. [CrossRef] [PubMed]

102. Zeidan, F.; Vago, D. Mindfulness meditation-based pain relief: A mechanistic account. Ann. N. Y. Acad. Sci. 2016, 1373, 114-127. [CrossRef]

103. Gerhart, J.I.; Burns, J.W.; Post, K.M.; Smith, D.A.; Porter, L.S.; Burgess, H.J.; Schuster, E.; Buvanendran, A.; Fras, A.M.; Keefe, F.J. Relationships Between Sleep Quality and Pain-Related Factors for People with Chronic Low Back Pain: Tests of Reciprocal and Time of Day Effects. Ann. Behav. Med. 2016, 51, 365-375. [CrossRef]

104. Burgess, H.J.; Burns, J.W.; Buvanendran, A.; Gupta, R.; Chont, M.; Kennedy, M.; Bruehl, S. Associations Between Sleep Disturbance and Chronic Pain Intensity and Function. Clin. J. Pain 2019, 35, 569-576. [CrossRef]

105. Serrat, M.; Almirall, M.; Musté, M.; Sanabria-Mazo, J.P.; Feliu-Soler, A.; Méndez-Ulrich, J.L.; Luciano, J.V.; Sanz, A. Effectiveness of a multicomponent treatment for fibromyalgia based on pain neuroscience education, exercise therapy, psychological support, and nature exposure (nat-fm): A pragmatic randomized controlled trial. J. Clin. Med. 2020, 9, 3348. [CrossRef] [PubMed]

106. Verkaik, R.; Busch, M.; Koeneman, T.; Berg, R.V.D.; Spreeuwenberg, P.; Francke, A.L. Guided imagery in people with fibromyalgia: A randomized controlled trial of effects on pain, functional status and self-efficacy. J. Health Psychol. 2013, 19, 678-688. [CrossRef] [PubMed]

107. Torres, E.; Pedersen, I.N.; Pérez-Fernández, I.J. Randomized Trial of a Group Music and Imagery Method (GrpMI) for Women with Fibromyalgia. J. Music Ther. 2018, 55, 186-220. [CrossRef] [PubMed]

108. Polaski, A.M.; Phelps, A.L.; Smith, T.J.; Helm, E.R.; Morone, E.N.; Szucs, A.K.; Kostek, M.C.; Kolber, B.J. Integrated Meditation and Exercise Therapy: A Randomized Controlled Pilot of a Combined Nonpharmacological Intervention Focused on Reducing Disability and Pain in Patients with Chronic Low Back Pain. Pain Med. 2021, 22, 444-458. [CrossRef]

109. Kahn, P.H., Jr.; Friedman, B.; Gill, B.; Hagman, J.; Severson, R.L.; Freier, N.G.; Feldman, E.N.; Carrère, S.; Stolyar, A. A plasma display window?-The shifting baseline problem in a technologically mediated natural world. J. Environ. Psychol. 2008, 28, 192-199. [CrossRef]

110. Craighead, W.E.; Dunlop, B.W. Combination Psychotherapy and Antidepressant Medication Treatment for Depression: For Whom, When, and How. Annu. Rev. Psychol. 2014, 65, 267-300. [CrossRef]

111. Hawton, K.; i Comabella, C.C.; Haw, C.; Saunders, K. Risk factors for suicide in individuals with depression: A systematic review. J. Affect. Disord. 2013, 147, 17-28. [CrossRef]

112. Alexopoulos, G.S. Depression in the elderly. Lancet 2005, 365, 1961-1970. [CrossRef]

113. Sarris, J.; O’Neil, A.; Coulson, C.E.; Schweitzer, I.; Berk, M. Lifestyle medicine for depression. BMC Psychiatry 2014, $14,107$. [CrossRef] 
114. Zhang, R.; Zhang, C.-Q.; Rhodes, R.E. The pathways linking objectively-measured greenspace exposure and mental health: A systematic review of observational studies. Environ. Res. 2021, 198, 111233. [CrossRef]

115. Oh, B.; Lee, K.J.; Zaslawski, C.; Yeung, A.; Rosenthal, D.; Larkey, L.; Back, M. Health and well-being benefits of spending time in forests: Systematic review. Environ. Health Prev. Med. 2017, 22, 1-11. [CrossRef] [PubMed]

116. Bratman, G.N.; Hamilton, J.P.; Daily, G.C. The impacts of nature experience on human cognitive function and mental health. Ann. N. Y. Acad. Sci. 2012, 1249, 118-136. [CrossRef] [PubMed]

117. Hirakawa, H.; Terao, T.; Muronaga, M.; Ishii, N. Adjunctive bright light therapy for treating bipolar depression: A systematic review and meta-analysis of randomized controlled trials. Brain Behav. 2020, 10, e01876. [CrossRef]

118. Braçe, O.; Garrido-Cumbrera, M.; Foley, R.; Correa-Fernández, J.; Suárez-Cáceres, G.; Lafortezza, R. Is a View of Green Spaces from Home Associated with a Lower Risk of Anxiety and Depression? Int. J. Environ. Res. Public Health 2020, 17, 7014. [CrossRef] [PubMed]

119. Van den Berg, M.; Wendel-Vos, W.; van Poppel, M.; Kemper, H.; van Mechelen, W.; Maas, J. Health benefits of green spaces in the living environment: A systematic review of epidemiological studies. Urban For. Urban Greening 2015, 14, 806-816. [CrossRef]

120. Yao, W.; Chen, F.; Wang, S.; Zhang, X. Impact of Exposure to Natural and Built Environments on Positive and Negative Affect: A Systematic Review and Meta-Analysis. Front. Public Health. 2021, 9. [CrossRef]

121. Mcmahan, E.A.; Estes, D. The effect of contact with natural environments on positive and negative affect: A meta-analysis. $J$. Posit. Psychol. 2015, 10, 507-519. [CrossRef]

122. Perera, S.; Eisen, R.; Bhatt, M.; Bhatnagar, N.; de Souza, R.; Thabane, L.; Samaan, Z. Light therapy for non-seasonal depression: Systematic review and meta-analysis. BJPsych Open 2016, 2, 116-126. [CrossRef]

123. Tao, L.; Jiang, R.; Zhang, K.; Qian, Z.; Chen, P.; Lv, Y.; Yao, Y. Light therapy in non-seasonal depression: An update meta-analysis Psychiatry Res. 2020, 291, 113247. [CrossRef]

124. Lam, R.W. Morning light therapy for winter depression: Predictors of response. Acta Psychiatr. Scand. 1994, 89, 97-101. [CrossRef]

125. Pjrek, E.; Friedrich, M.-E.; Cambioli, L.; Dold, M.; Jäger, F.; Komorowski, A.; Lanzenberger, R.; Kasper, S.; Winkler, D. The Efficacy of Light Therapy in the Treatment of Seasonal Affective Disorder: A Meta-Analysis of Randomized Controlled Trials. Psychother. Psychosom. 2019, 89, 17-24. [CrossRef] [PubMed]

126. Srisurapanont, K.; Samakarn, Y.; Kamklong, B.; Siratrairat, P.; Bumiputra, A.; Jaikwang, M.; Srisurapanont, M. Blue-wavelength light therapy for post-traumatic brain injury sleepiness, sleep disturbance, depression, and fatigue: A systematic review and network meta-analysis. PLoS ONE 2021, 16, e0246172. [CrossRef] [PubMed]

127. Cooney, G.M.; Dwan, K.; Greig, C.; Lawlor, A.D.; Rimer, J.; Waugh, F.R.; McMurdo, M.; Mead, E.G. Exercise for depression. Cochrane Database Syst. Rev. 2013, CD004366. [CrossRef]

128. Gujral, S.; Aizenstein, H.; Reynolds, C.F., III; Butters, M.A.; Erickson, K.I. Exercise effects on depression: Possible neural mechanisms. Gen. Hosp. Psychiatry 2017, 49, 2-10. [CrossRef] [PubMed]

129. Kandola, A.; Ashdown-Franks, G.; Hendrikse, J.; Sabiston, C.M.; Stubbs, B. Physical activity and depression: Towards understanding the antidepressant mechanisms of physical activity. Neurosci. Biobehav. Rev. 2019, 107, 525-539. [CrossRef] [PubMed]

130. Brinsley, J.; Schuch, F.; Lederman, O.; Girard, D.; Smout, M.; Immink, A.M.; Stubbs, B.; Firth, J.; Davison, K.; Rosenbaum, S. Effects of yoga on depressive symptoms in people with mental disorders: A systematic review and meta-analysis. Br. J. Sports Med. 2020, 55, 992-1000. [CrossRef]

131. Long, J.; Briggs, M.; Astin, F. Overview of Systematic Reviews of Mindfulness Meditation-based Interventions for People With Long-term Conditions. Adv. Mind-Body Med. 2018, 31, 26-36.

132. Alsaraireh, F.A.; Aloush, S.M. Mindfulness Meditation Versus Physical Exercise in the Management of Depression Among Nursing Students. J. Nurs. Educ. 2017, 56, 599-604. [CrossRef]

133. Sharma, A.; Barrett, M.S.; Cucchiara, A.J.; Gooneratne, N.S.; Thase, M.E. A Breathing-Based Meditation Intervention for Patients With Major Depressive Disorder Following Inadequate Response to Antidepressants. J. Clin. Psychiatry 2016, 78, e59-e63. [CrossRef]

134. Zaccaro, A.; Piarulli, A.; Laurino, M.; Garbella, E.; Menicucci, D.; Neri, B.; Gemignani, A. How Breath-Control Can Change Your Life: A Systematic Review on Psycho-Physiological Correlates of Slow Breathing. Front. Hum. Neurosci. 2018, 12, 353. [CrossRef]

135. Srivastava, A.; Kuppili, P.P.; Gupta, T.; Nebhinani, N.; Chandani, A. Kriya Yoga in Patients with Depressive Disorders: A Pilot Study. J. Neurosci. Rural Pr. 2021, 12, 362-367. [CrossRef] [PubMed]

136. Sánchez-Vidaña, D.I.; Ngai, S.P.; He, W.; Chow, J.K.-W.; Lau, B.W.-M.; Tsang, H.W. The Effectiveness of Aromatherapy for Depressive Symptoms: A Systematic Review. Evid.-Based Complement. Altern. Med. 2017, 2017, 1-21. [CrossRef] [PubMed]

137. Baglioni, C.; Battagliese, G.; Feige, B.; Spiegelhalder, K.; Nissen, C.; Voderholzer, U.; Lombardo, C.; Riemann, D. Insomnia as a predictor of depression: A meta-analytic evaluation of longitudinal epidemiological studies. J. Affect. Disord. 2011, 135, 10-19. [CrossRef] [PubMed]

138. Monteleone, P.; Martiadis, V.; Maj, M. Circadian rhythms and treatment implications in depression. Prog. Neuro-Psychopharmacol. Biol. Psychiatry 2011, 35, 1569-1574. [CrossRef]

139. Ng, Q.X.; Venkatanarayanan, N.; Ho, C.Y.X. Clinical use of Hypericum perforatum (St John's wort) in depression: A meta-analysis. J. Affect. Disord. 2017, 210, 211-221. [CrossRef]

140. Apaydin, E.A.; Maher, A.R.; Shanman, R.; Booth, M.S.; Miles, J.N.V.; Sorbero, M.E.; Hempel, S. A systematic review of St. John's wort for major depressive disorder. Syst. Rev. 2016, 5, 148. [CrossRef] 
141. Psaltopoulou, T.; Sergentanis, T.N.; Panagiotakos, D.B.; Sergentanis, I.N.; Kosti, R.; Scarmeas, N. Mediterranean diet, stroke, cognitive impairment, and depression: A meta-analysis. Ann. Neurol. 2013, 74, 580-591. [CrossRef]

142. Klainin-Yobas, P.; Oo, W.N.; Yew, P.Y.S.; Lau, Y. Effects of relaxation interventions on depression and anxiety among older adults: A systematic review. Aging Ment. Health 2015, 19, 1043-1055. [CrossRef]

143. Xiao, P.; Ding, S.; Duan, Y.; Li, L.; Zhou, Y.; Luo, X.; Xie, J.; Cheng, A.S. Effect of Light Therapy on Cancer-Related Fatigue: A Systematic Review and Meta-Analysis. J. Pain Symptom Manag. 2021, 63, e188-e202. [CrossRef]

144. Lindskov, F.O.; Iversen, H.K.; West, A.S. Clinical outcomes of light therapy in hospitalized patients-A systematic review. Chrono.-Int. 2021, 39, 299-310. [CrossRef]

145. Cheng, K.; Martin, L.F.; Slepian, M.J.; Patwardhan, A.M.; Ibrahim, M.M. Mechanisms and Pathways of Pain Photobiomodulation: A Narrative Review. J. Pain 2021, 22, 763-777. [CrossRef] [PubMed]

146. Connolly, L.J.; Ponsford, J.L.; Rajaratnam, S.M.W.; Lockley, S.W. Development of a Home-Based Light Therapy for Fatigue Following Traumatic Brain Injury: Two Case Studies. Front. Neurol. 2021, 12, 1559. [CrossRef] [PubMed]

147. Connolly, L.J.; Rajaratnam, S.M.W.; Murray, J.M.; Spitz, G.; Lockley, S.W.; Ponsford, J.L. Home-based light therapy for fatigue following acquired brain injury: A pilot randomized controlled trial. BMC Neurol. 2021, 21, 1-13. [CrossRef] [PubMed]

148. Tähkämö, L.; Partonen, T.; Pesonen, A.-K. Systematic review of light exposure impact on human circadian rhythm. Chronobiol. Int. 2019, 36, 151-170. [CrossRef] [PubMed]

149. Shechter, A.; Kim, E.W.; St-Onge, M.-P.; Westwood, A.J. Blocking nocturnal blue light for insomnia: A randomized controlled trial. J. Psychiatr. Res. 2017, 96, 196-202. [CrossRef] [PubMed]

150. Baglioni, C.; Nanovska, S.; Regen, W.; Spiegelhalder, K.; Feige, B.; Nissen, C.; Reynolds, C.F.; Riemann, D. Sleep and mental disorders: A meta-analysis of polysomnographic research. Psychol. Bull. 2016, 142, 969-990. [CrossRef]

151. Leff, B. Defining and disseminating the hospital-at-home model. Can. Med Assoc. J. 2009, 180, 156-157. [CrossRef]

152. Martin, K.; Nanu, L.; Kwon, W.-S.; Martin, D. Small Garden, Big Impact: Emotional and Behavioral Responses of Visitors to a Rooftop Atrium in a Major Hospital. HERD: Heal. Environ. Res. Des. J. 2021, 14, 274-287. [CrossRef]

153. Totaforti, S. Applying the benefits of biophilic theory to hospital design. City Territ. Arch. 2018, 5, 1. [CrossRef]

154. Abdelaal, M.S.; Soebarto, V. Biophilia and Salutogenesis as restorative design approaches in healthcare architecture. Arch. Sci. Rev. 2019, 62, 195-205. [CrossRef]

155. Ibrahim, T.; Gabr, H.; Khodeir, L.; Aboubakr, D. Synergetic approach for biophilic healing interior design for paediatric cancer. J. Eng. Appl. 2020, 67, 1435-1453.

156. Miller, E.; Burton, L.O. Redesigning aged care with a biophilic lens: A call to action. Cities Health 2020, 1-13. [CrossRef]

157. Taylor, S.P.; Golding, L. Economic Considerations for Hospital at Home Programs: Beyond the Pandemic. J. Gen. Intern. Med. 2021, 36, 3861-3864. [CrossRef] [PubMed]

158. Levine, D.M.; Ouchi, K.; Blanchfield, B.; Saenz, A.; Burke, K.; Paz, M.; Diamond, K.; Pu, C.T.; Schnipper, J.L. Hospital-Level Care at Home for Acutely Ill Adults. Ann. Intern. Med. 2019, 172, 77. [CrossRef] [PubMed]

159. McGee, B.; Park, N.; Portillo, M.; Bosch, S.; Swisher, M. Diy Biophilia: Development of the Biophilic Interior Design Matrix as a Design Tool. J. Inter. Des. 2019, 44, 201-221. [CrossRef]

160. McGee, B.; Park, N.-K. Colour, Light, and Materiality: Biophilic Interior Design Presence in Research and Practice. Interiority 2022, 5, 27-52. [CrossRef]

161. Noser, E.A.; Klages, K.L.; Gamwell, K.L.; Brammer, C.N.; Hommel, A.K.; Ramsey, R.R. A systematic evaluation of primary headache management apps leveraging behavior change techniques. Cephalalgia 2021. [CrossRef]

162. Hommel, K.A.; Carmody, J.; Hershey, A.D.; Holbein, C.; Kabbouche-Samaha, M.; Peugh, J.; Powers, S. Digital Therapeutic Self-Management Intervention in Adolescents With Migraine: Feasibility and Preliminary Efficacy of "Migraine Manager". Headache: J. Head Face Pain 2020, 60, 1103-1110. [CrossRef]

163. Rubin, R. Virtual Reality Device Is Authorized to Relieve Back Pain. JAMA 2021, 326, 2354. [CrossRef]

164. Garcia, L.M.; Birckhead, B.J.; Krishnamurthy, P.; Sackman, J.; Mackey, I.G.; Louis, R.G.; Salmasi, V.; Maddox, T.; Darnall, B.D. An 8-Week Self-Administered At-Home Behavioral Skills-Based Virtual Reality Program for Chronic Low Back Pain: Double-Blind, Randomized, Placebo-Controlled Trial Conducted During COVID-19. J. Med. Internet Res. 2021, 23, e26292. [CrossRef]

165. Moshe, I.; Terhorst, Y.; Philippi, P.; Domhardt, M.; Cuijpers, P.; Cristea, I.; Pulkki-Råback, L.; Baumeister, H.; Sander, L.B. Digital interventions for the treatment of depression: A meta-analytic review. Psychol. Bull. 2021, 147, 749-786. [CrossRef] [PubMed]

166. Moberg, C.; Niles, A.; Beermann, D. Guided Self-Help Works: Randomized Waitlist Controlled Trial of Pacifica, a Mobile App Integrating Cognitive Behavioral Therapy and Mindfulness for Stress, Anxiety, and Depression. J. Med. Internet Res. 2019, 21, e12556. [CrossRef] [PubMed] 